\title{
Perancangan dan simulasi Turbin Angin Sumbu Horizontal (TASH) dengan variasi jumlah blade dan variasi sudut pitch serta analisis power, torque dan thrust menggunakan aplikasi Q-Blade
}

\author{
Muhammad Abdul Ghofur ${ }^{1, *}$, Muhammad Irsan Pratama Putra ${ }^{2}$, Rindu \\ Alriavindra Funny ${ }^{3}$ \\ ${ }^{1,2}$ Prodi Teknik Aeronautika Pertahanan, Akademi Angkatan Udara \\ ${ }^{3}$ Departemen Teknik Dirgantara, Sekolah Tinggi Teknologi Adisucipto \\ Email Korespondensi : ${ }^{*}$ m_abdulghofur@aau.ac.id
}

\begin{abstract}
Turbin angin memanfaatkan energi kinetik dari angin dan kemudian mengkonversinya menjadi energi listrik. Ada dua tipe turbin angin yaitu Turbin Angin dengan Sumbu Horizontal (TASH) dan Turbin Angin dengan Sumbu Vertical (TASV). Turbin Angin Sumbu Horisontal adalah jenis turbin angin dimana sumbu rotasi turbin nya diorientasikan secara sejajar dengan arah angin agar menghasilkan power. Sedangkan Turbin Angin Sumbu Vertikal adalah jenis turbin angin dimana sumbu rotasi turbin ini tegak lurus dengan arah angin atau permukaan pemasangan. Dalam penelitian ini dilakukan perancangan Simulasi Turbin Angin Sumbu Horizontal (TASH) dengan memvariasikan jumlah blade $3,4,5,6$, sudut pitch $0^{\circ}, 6^{\circ}, 10^{\circ}$ dan variasi kecepatan angin serta menganalisis performance yang dihasilkan oleh turbin angin tersebut dengan parameter Power, Torque dan Thrust. Berdasarkan perancangan dan analisis yang dilaksanakan, diperoleh kesimpulan bahwa nilai power paling besar pada turbin dengan jumlah 3 blade, sudut $6^{\circ}$ yaitu sebesar 2837 watt saat kecepatan angin $20 \mathrm{~m} / \mathrm{s}$ dan 1401,00 rpm. Nilai rotor torque terbesar pada turbin dengan jumlah 6 blade, sudut pitch $0^{\circ}$ yaitu sebesar 34,5 Nm pada kecepatan angin $20 \mathrm{~m} / \mathrm{s}$ dan kecepatan rotasi $601,00 \mathrm{rpm}$. Nilai thrust terbesar dihasilkan oleh turbin angin dengan jumlah 6 blade, sudut $10^{\circ}$ yaitu sebesar $363,11 \mathrm{~N}$ ketika kecepatan angin $20 \mathrm{~m} / \mathrm{s}$ dan kecepatan rotasi 1401,00 rpm. Penelitian ini juga melakukan pengujian pada kecepatan angin rata-rata di Indonesia yaitu dengan kecepatan $12 \mathrm{~m} / \mathrm{s}$ dan kecepatan rotasi $300 \mathrm{rpm}$, diperoleh turbin angin paling efesien adalah dengan jumah blade 6 dengan menghasilkan power 332,383 watt, rotor torque 610,545 Nm dan thrust 57,582 N.
\end{abstract}

Keywords: Turbin Angin Sumbu Horisontal (TASH), Q-Blade, Jumlah Blade, Sudut Pitch, Power, Rotor Torque, Thrust.

\section{Pendahuluan}

Energi merupakan suatu kebutuhan yang sangat di butuhkan dalam kehidupan, dimana semua aktifitas yang kita lakukan membutuhkan energi, seperti energi untuk metabolisme tubuh, kendaraan, industri, listrik, dan lain-lain. Di mana semua itu membutuhkan sumber atau penghasil energi, sesuai hukum kekalan energi dimana energi tidak dapat diciptakan dan tidak dapat dimusnahkan, namun energi dapat diubah bentuknya atau di transformasi untuk dapat memenuhi kebutuhan kita sehari-hari. Di era sekarang energi yang berasal dari fosil dan nuklir mulai berkurang dan mempunyai resiko yang besar untuk kedepanya, oleh karena itu banyak peneliti mencari dan menemukan energi alternatif yang ramah 
lingkungan atau yang disebut energi terbarukan, di mana energi ini berasal dari alam yang diolah untuk dapat memenuhi kebutuhan kita serta tidak merusak alam. Contohnya energi air, angin, cahaya matahari, gelombang air laut, dan lain-lain. Angin merupakan salah satu dari energi yang dapat di olah dengan memanfaat energi kinetik dari pergerakan angin yang menggerakan bilah-bilah turbin, lalu turbin bergerak memutari sumbu rotasi, dimana hasil pergerakan turbin memutar generator yang dapat menghasilkan energi baru yaitu energi listrik. Turbin adalah sebuah mesin penggerak yang memanfaatkan energi dari aliran fluida seperti air, uap, dan gas untuk menggerakkan beban seperti generator, pompa, kompresor, baling-baling, dan lain sebagainya. Proses yang terjadi pada turbin dimulai dari aliran secara kontinu yang menumbuk baling-baling rotor, membuat baling-baling rotor tersebut berputar sehingga poros pada rotor juga ikut berputar atau bergerak. Perputaran poros inilah yang kemudian dimanfaatkan untuk menggerakkan dinamo, generator, atau mesin lainnya. Proses perputaran poros ini akan menghasilkan energi listrik. Turbin angin pada prinsipnya dapat dibedakan atas dua jenis turbin berdasarkan arah putarannya. Turbin angin yang berputar pada poros horizontal disebut dengan turbin angin sumbu horizontal (TASH) atau Horizontal Axis Wind Turbine (HAWT), sementara yang berputar pada poros vertikal disebut dengan turbin angin sumbu vertikal (TASV) atau Vertical Axis Wind Turbine (VAWT). Firman Aryanto, I Made Mara, Made Nuarsa melakukan penelitian Pengaruh Kecepatan Angin dan Variasi Jumlah Sudu Terhadap Unjuk Kerja Turbin Angin Poros Horizontal. Diperoleh bahwa semakin besar kecepatan angin maka putaran yang dihasilkan juga semakin besar [10]. Bono melakukan Eksperimen Turbin Angin Poros Horizontal Tipe Kerucut Terpancung Dengan Variasi Sudut Sudu Untuk Pembangkit Listrik Tenaga Angin. Diperoleh bahwa nilai efisiensi tertinggi untuk setiap bukaan sudut sudu, pada kecepatan angin $5 \mathrm{~m} / \mathrm{s}$ adalah sebagai berikut: Sudut sudu $60^{\circ}$, efisiensi sebesar $15,35 \%$, Sudut sudu $45^{\circ}$, efisiensi sebesar $19,64 \%$, Sudut sudu $30^{\circ}$, efisiensi sebesar $21,27 \%$, Sudut sudu $15^{\circ}$, efisiensi sebesar 16,22\% [11]. Arga Gideon Sarwando, Untung Budiarto, Ahmad Fauzan Zakki melakukan penelitian Analisa Efektifitas Wind Turbine Sumbu Horizontal Dengan Variasi Jumlah dan Jenis Airfoil Sebagai Sumber Energi Listrik Tambahan Pada Fisheries Inspection. Diperoleh bahwa jenis airfoil NACA 0018 memiliki yang paling tinggi dari NACA 0015 dan NACA 0025, dengan torsi 351,72 Nm, daya $11,05 \mathrm{KW}$, dan coefficient power 0,488 [12].

Dalam penelitian ini dilakukan perancangan Simulasi Turbin Angin Sumbu Horizontal (TASH) dengan variasi jumlah blade $3,4,5,6$, variasi sudut pitch $0^{\circ}, 6^{\circ}, 10^{\circ}$ dan variasi kecepatan angin serta menganalisis performance yang dihasilkan oleh turbin angin tersebut dengan parameter Power, Torque dan Thrust.

\section{Metode Penelitian}

Dalam penelitian kali ini dilaksanakan perancangan Turbin Angin Sumbu Horizontal (TASH) menggunakan Software Q-Blade guna menghetahui efektifitas dan efisiensi dari Performance Turbin Angin Sumbu Horizontal (TASH). Hasil performance yang didapatkan sebagai analasis untuk mengatahui karakterisitik turbin angin yang efektif dan efisien yang dapat digunakan sebagai acuan pembuatan turbin angin. Perancangan turbin angin sumbu horizontal terdiri atas variasi jumlah blade, dan sudut pitch. Dalam penelitian ini juga akan menganalisis hasil performance berupa power, thrust, dan rotor towque dari turbin yang dihasilkan. Adapun dalam perancangan turbin angin sumbu horizontal tersebut akan dibuat rancangan dengan karakteristik sebagai berikut: Jumlah blade yang digunakan adalah 3, 4, 5, dan 6 buah dan besar sudut pitch yang digunakan adalah $0^{\circ}, 6^{\circ}, 10^{\circ}$. Dalam melaksanakan perancangan simulasi turbin angin sumbu horizintal, penulis menggunakan software Q-Blade. Software ini digunakan untuk membuat simulasi sebagai gambaran pergerakan turbin angin sumbu horizontal. 


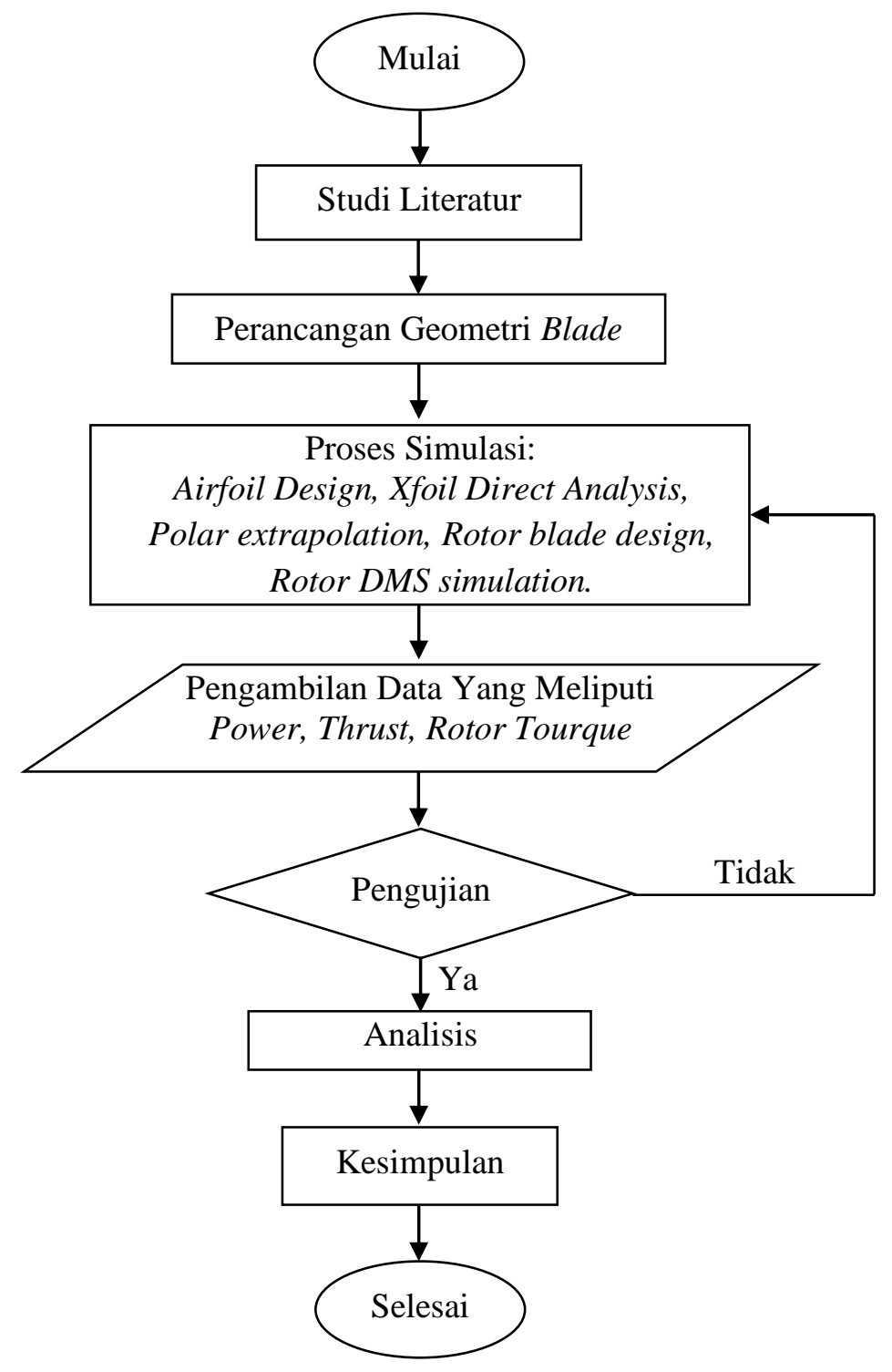

Gambar 1. Alur dalam penelitian

\section{Hasil dan Analisis}

Karakteristik Turbin Angin Sumbu Horizontal (TASH) antara lain:

Panjang blade

Radius Hub

$=0,5 \mathrm{~m}$

Jenis Airfoil

$=0,1 \mathrm{~m}$

Daya (We)

$=$ NACA 0018

$=220 \mathrm{Watt}$

Efisiensi Bilah $(\eta \mathrm{b})$

$=0,3-0,4$

Efisiensi Transmisi ( $\eta \mathrm{t})$

$=0,9$

Efisiensi generator ( $\eta \mathrm{g}$ )

$=0,9$

Efisiensi Controller $(\eta \mathrm{c})$

$=0,9$

Efisiensi Sistem $K$

$$
\begin{aligned}
& =\eta b \times \eta t \times \eta g \times \eta c \\
& =0,3 \times 0,9 \times 0,9 \times 0,9=0,2187=0,22
\end{aligned}
$$




$$
\begin{array}{ll}
\text { Daya angin tiap Efisiensi }(\mathrm{W} \alpha) & =W \alpha=\frac{W e}{K}=\frac{220}{0,22}=1005,9 \text { Watt } \\
\text { Kecepatan Max }\left(\mathrm{V}_{\text {Max }}\right) & =12 \mathrm{~m} / \mathrm{s} \\
\text { Luas Sapuan (A) } & =\frac{2 W \sigma}{\rho V \max ^{\mathrm{g}}}=\frac{2 \times 1005,9}{1,225 \times 12^{\mathrm{g}}}=0,950 \mathrm{~m}^{2} \\
\text { Jari- jari tiap Efisiensi (R) } & =\sqrt{A \times \pi}=\sqrt{0.950 \times 3.14}=0,550
\end{array}
$$

\begin{tabular}{|c|c|c|c|c|c|c|c|c|c|c|}
\hline \multirow[b]{2}{*}{$\begin{array}{l}\text { Kapasitas } \\
\text { daya listrik } \\
\text { (We) }\end{array}$} & \multicolumn{5}{|c|}{ Efisiensi } & \multirow[b]{2}{*}{$\begin{array}{l}\text { Daya } \\
\text { Angin }\end{array}$} & \multirow[b]{2}{*}{ V Max } & \multirow[b]{2}{*}{$\begin{array}{l}\text { Luas } \\
\text { sapuan }\end{array}$} & \multirow[b]{2}{*}{$\begin{array}{c}\text { Jari-jari } \\
(\mathrm{R})\end{array}$} & \multirow[b]{2}{*}{$\begin{array}{c}\text { Jari-jari } \\
\text { yang } \\
\text { digunakan }\end{array}$} \\
\hline & Bilah & Transmisi & Generator & Controller & Sistem & & & & & \\
\hline 220 & $\begin{array}{l}0,3 \\
0,4\end{array}$ & 0,9 & 0,9 & 0,9 & $\begin{array}{l}0,22 \\
0,29\end{array}$ & $\begin{array}{c}1005,9 \\
754,5\end{array}$ & 12 & $\begin{array}{l}0,950 \\
0,713\end{array}$ & $\begin{array}{l}0,550 \\
0,476\end{array}$ & 0,5 \\
\hline
\end{tabular}

Sehingga jari-jari yang di gunakan adalah kisaran efisiensi atas dan bawah yaitu $0,5 \mathrm{~m}$

Tabel 1. Estimasi nilai kapasitas daya listrik serta efisiensi bilah

blade adalah $6-8$, dalam penelitian ini menggunakan 7 sebagai nilai tengah dari TSR 3 blade

Tabel 2. Jenis dan ukuran airfoil

\begin{tabular}{ccccc}
\hline TSR & Airfoil & $\mathrm{Cl} / \mathrm{Cd}$ & $\mathrm{Cr}$ & Jumlah Bilah (B) \\
\hline 7 & 0018 & 78,43 & 0.1 & 3 \\
\hline
\end{tabular}

Berikut merupakan contoh perhitungan pada elemen 1:

Elemen $(\mathrm{n}) \quad=$ Bagian-bagian blade yang di bagi secara parsial

Jari-jari (r) $\quad=r_{0}+\left[\left(\frac{R-r_{0}}{n_{10}}\right) \times n\right]=0,25+\left[\left(\frac{0,5-0,025}{10}\right) \times 1\right]=0,095 \mathrm{~m}$

$\operatorname{TSR}$ Parsial $\left(\lambda_{\mathrm{r}}\right) \quad=\frac{r}{R} \times \lambda_{R}=\frac{0,095}{0,5} \times 7=1,33$

Koefisien Lift $(\mathrm{Cl})=\frac{16 \pi \times R \times\left(\frac{R}{r}\right)}{9 \lambda^{2} \times B \times C r}=\frac{16(3,14) \times 0,5 \times\left(\frac{0,5}{0,095}\right)}{9(7)^{2} \times 3 \times 0,1}=1,00$

Flow Angle $(\Phi)=\frac{2}{3} \tan ^{-1} \frac{1}{\lambda_{r}}=\frac{2}{3} \tan ^{-1} \frac{1}{0,095}=28,53$

Tabel 3. Geometri Blade 
Perancangan Simulasi Turbin Angin Sumbu Horizontal (TASH) dengan variasi jumlah blade...

\begin{tabular}{ccccccc}
1 & 0,095 & 1,33 & 1,00 & 12,20 & 28,53 & 16,33 \\
2 & 0,140 & 1,96 & 0,68 & 7,29 & 19,92 & 12,63 \\
3 & 0,185 & 2,59 & 0,51 & 5,20 & 15,13 & 9,93 \\
4 & 0,230 & 3,22 & 0,41 & 4,09 & 12,11 & 8,02 \\
5 & 0,275 & 3,85 & 0,35 & 3,30 & 10,05 & 6,75 \\
6 & 0,320 & 4,48 & 0,30 & 2,75 & 8,59 & 5,84 \\
7 & 0,365 & 5,11 & 0,26 & 2,29 & 7,49 & 5,20 \\
8 & 0,410 & 5,74 & 0,23 & 2,10 & 6,65 & 4,55 \\
9 & 0,455 & 6,37 & 0,21 & 1,90 & 5,97 & 4,07 \\
10 & 0,500 & 7,00 & 0,19 & 1,73 & 5,42 & 3,69 \\
\hline
\end{tabular}

Pada tabel diatas dapat dilihat bahwa sudut twist yang dihasilkan sangat ekstrim yaitu $3^{\circ}$ sampai dengan $20^{\circ}$, namun sudut yang ekstrim dapat membuat proses pembuatan menjadi sulit hingga pada tahap selanjutnya akan dilakukan linearisasi sudut. Tabel tambahan seperti pada tabel dibawah ini dimana elemen ke-7 dan ke-8 digunakan karena $75 \%$ jari-jari merupakan titik paling optimal untuk di buat persamaan garis linear.

Sudut twist $=-0,65 r+10,4=-0,65(0,95)+10,4=10,34$

Tabel 4. Geometri Blade dengan tambahan linearisasi

\begin{tabular}{ccccccccc}
\hline Elemen & $\mathrm{r}$ & $\begin{array}{c}\text { TSR } \\
\text { Parsial }\end{array}$ & $\mathrm{Cl}$ & Alpha & $\begin{array}{c}\text { Flow Angle } \\
(\mathrm{deg})\end{array}$ & $\begin{array}{c}\text { Twist } \\
(\mathrm{beta}) \\
(\mathrm{deg})\end{array}$ & $\begin{array}{c}\text { Twist } \\
\text { Linear } \\
75 \%\end{array}$ & $\begin{array}{c}\text { Twist } \\
\text { Linear } \\
75 \%\end{array}$ \\
\hline 0 & 0,05 & 0,70 & 1,90 & 24,00 & 44,18 & 20,18 & & 10,37 \\
1 & 0,095 & 1,33 & 1,00 & 12,20 & 28,53 & 16,33 & & 10,34 \\
2 & 0,140 & 1,96 & 0,68 & 7,29 & 19,92 & 12,63 & & 10,31 \\
3 & 0,185 & 2,59 & 0,51 & 5,20 & 15,13 & 9,93 & & 10,28 \\
4 & 0,230 & 3,22 & 0,41 & 4,09 & 12,11 & 8,02 & & 10,25 \\
5 & 0,275 & 3,85 & 0,35 & 3,30 & 10,05 & 6,75 & & 10,22 \\
6 & 0,320 & 4,48 & 0,30 & 2,75 & 8,59 & 5,84 & & 10,19 \\
7 & 0,365 & 5,11 & 0,26 & 2,29 & 7,49 & 5,20 & 5,20 & 10,16 \\
8 & 0,410 & 5,74 & 0,23 & 2,10 & 6,65 & 4,55 & 4,55 & 10,13 \\
9 & 0,455 & 6,37 & 0,21 & 1,90 & 5,97 & 4,07 & & 10,10 \\
10 & 0,500 & 7,00 & 0,19 & 1,73 & 5,42 & 3,69 & & 10,08 \\
\hline
\end{tabular}

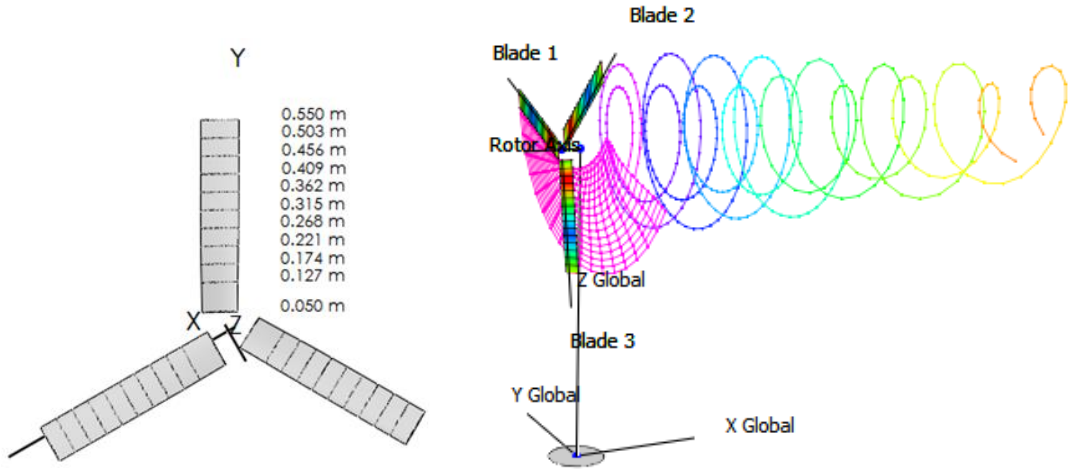

Gambar 2. Simulasi TASH

Hasil dari pengujian menggunakan Q-Blade yang telah didapatkan berupa nilai Power, Thrust, Rotational speed, Rotor Tourqe dengan variasi jumlah blade dan sudut pitch dengan kecepatan angin dari $1 \mathrm{~m} / \mathrm{s}$ sampai dengan $20 \mathrm{~m} / \mathrm{s}$. Hasil grafik pada turbin angin dengan 3 blade dengan sudut pitch $0^{\circ}$ telah di dapatkan data semakin besar kecepatan angin dan rotational speed akan semakin besar juga performance yang di hasilkan. 

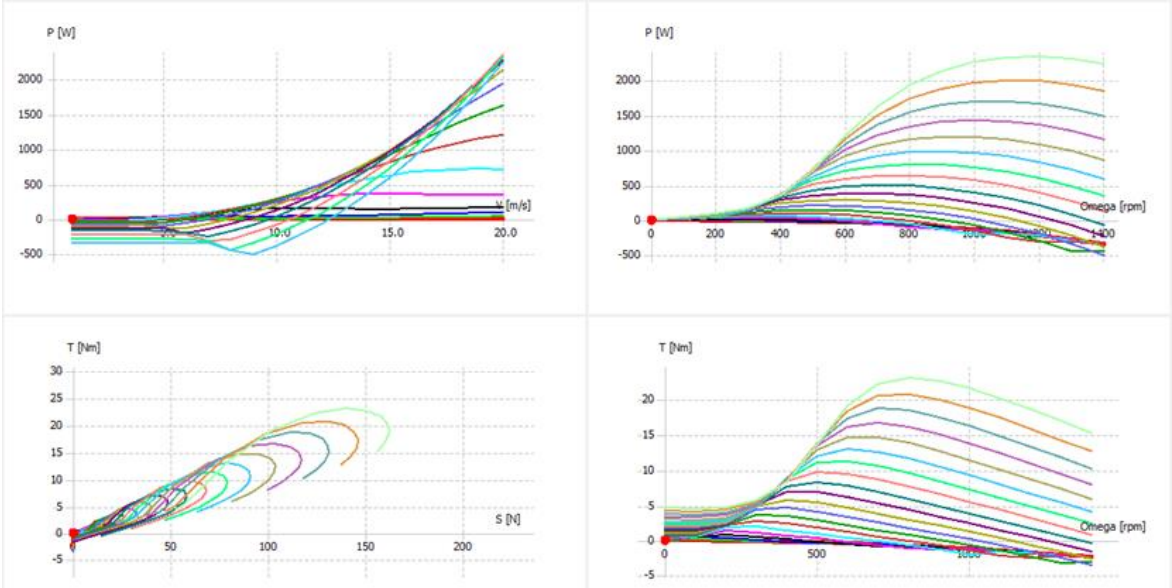

Gambar 3. Grafik Hasil Performance turbin angin sumbu horizontal 3 blade pada sudut pitch $0^{\circ}$

Dari Gambar 3, didapatkan data bahwa Power paling besar ketika kecepatan $20 \mathrm{~m} / \mathrm{s}$ dengan kecepatan rotasi 1201,00 rpm yaitu 2324 watt, untuk power yang cenderung stabil saat kecepatan rotasi 601,00 rpm sampai dengan 901,00 rpm, sementara untuk kecepatan rotasi kurang dari atau sama dengan 501,00 rpm akan turun pada kecepatan angin $10 \mathrm{~m} / \mathrm{s}$ sampai dengan $17 \mathrm{~m} / \mathrm{s}$. Rotor torque yang di hasilkan paling besar adalah ketika kecepatan angin $20 \mathrm{~m} / \mathrm{s}$ dan kecepatan rotasi 801,00 rpm yaitu 22,95 $\mathrm{Nm}$ dengan Thrust 140,54 N, nilai thrust paling besar ketika kecepatan rotasi 1201,00 rpm yaitu 162,21 N. Ketika kecepatan angin $12 \mathrm{~m} / \mathrm{s}$ dan kecepatan rotasi $300 \mathrm{rpm}$ dapat menghasilkan power 152,676 watt.

Hasil grafik pada turbin angin dengan 3 blade dengan sudut pitch $6^{\circ}$ terjadi perubahan performance akibat sudut pitch yang diubah.
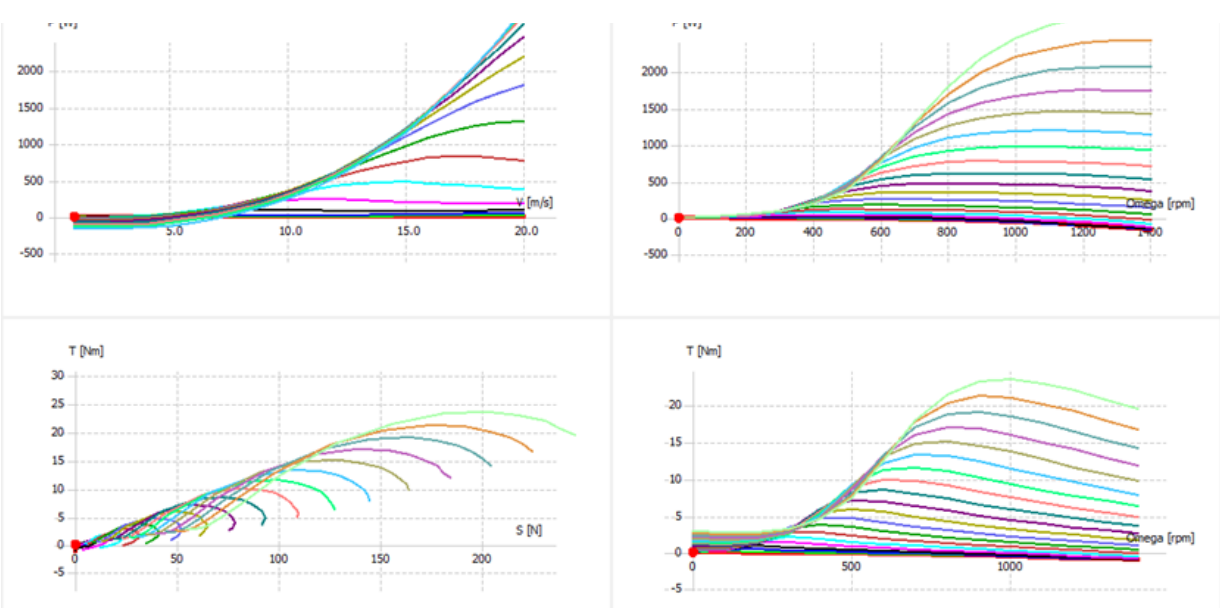

Gambar 4. Hasil Performance turbin angin sumbu horizontal 3 blade pada sudut pitch $6^{\circ}$

Dari Gambar 4 didapatkan data bahwa power maksimum yaitu 2837 watt saat kecepatan angin $20 \mathrm{~m} / \mathrm{s}$. pada sudut ini power cenderung satabil dari titik minimum sampai dengan maksimum, untuk power yang mengalami penurunan saat kecepatan angin $11 \mathrm{~m} / \mathrm{s}$ dengan kecepatan rotasi $\leq 601,00 \mathrm{rpm}$. Rotor torque yang di hasilkan paling besar adalah ketika kecepatan angin $20 \mathrm{~m} / \mathrm{s}$ dan kecepatan rotasi 1001,00 rpm yaitu 23,33 Nm dengan Thrust 203,09 N, nilai thrust paling besar ketika kecepatan rotasi 1401,00 rpm yaitu $245,63 \mathrm{~N}$.

Hasil grafik pada turbin angin dengan 3 blade dengan sudut pitch $10^{\circ}$ mengalami perubahan di mana grafik cenderung turun seperti yang terlihat pada Gambar 6. 

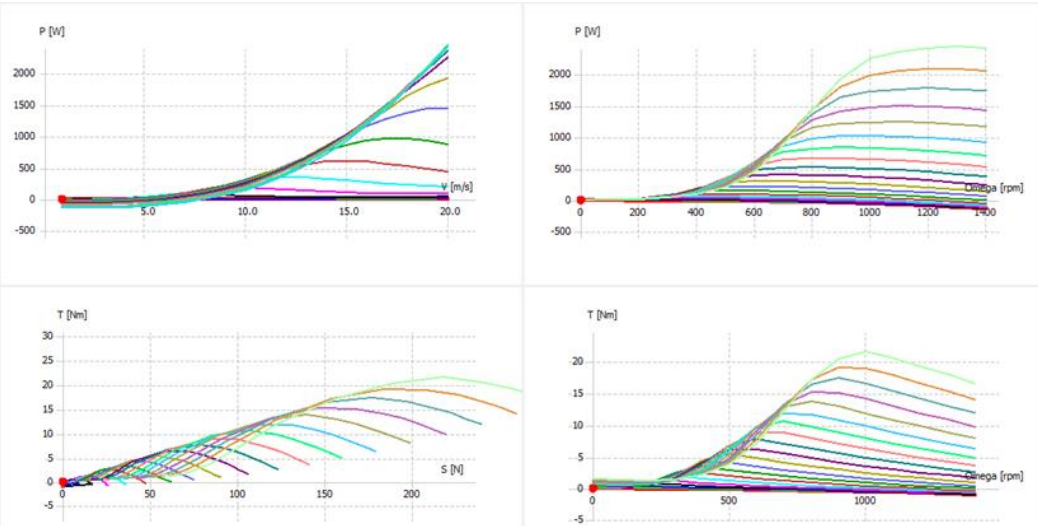

Gambar 5. Hasil Performance turbin angin sumbu horizontal 3 blade pada sudut pitch $10^{\circ}$

Pada Gambar 5 telah didapatkan hasil performance bahwa power paling besar adalah 2431,2 watt saat kecepatan angin $20 \mathrm{~m} / \mathrm{s}$ dan kecepatan rotasi 1301,00 rpm, dari grafik $\mathrm{P}$ vs V power cenderung stabil untuk naik dan tidak ada penurun power seiring bertambahnya kecepatan angin. Rotor torque yang di hasilkan besar saat kecepatan angin $20 \mathrm{~m} / \mathrm{s}$ dan kecepatan rotasi 1001,00 rpm yaitu 21,36 Nm dengan thrust yang di hasilkan 218,14 N, untuk Thrust paling besar didapatkan nilai 281,214 N saat kecepatan angin $20 \mathrm{~m} / \mathrm{s}$ dan kecepatan rotasi 1401,00 rpm. Dari data dia atas dapat disimpulkan bahwa power paling besar ketika sudut pitch $6^{\circ}$ dengan power 2837 watt, dan terdapat peningkatan nilai thrust di mana semakin besar sudut pitch juga maka akan semakin besar nilai thrust yang di hasilkan, pada sudut pitch $0^{\circ}$ grafik rotor torque terhadap thrust berbentuk sperti mata kail di mana perubahan sudut pitch juga megurangi nilai thrust dan rotor torque terhadap pengaruh angin dan kecepatan rotasi.

Hasil grafik pada turbin angin dengan 6 blade dengan sudut pitch $0^{\circ}$ telah di dapatkan data semakin besar kecepatan angin dan rotational speed akan semakin besar juga performance yang di hasilkan.
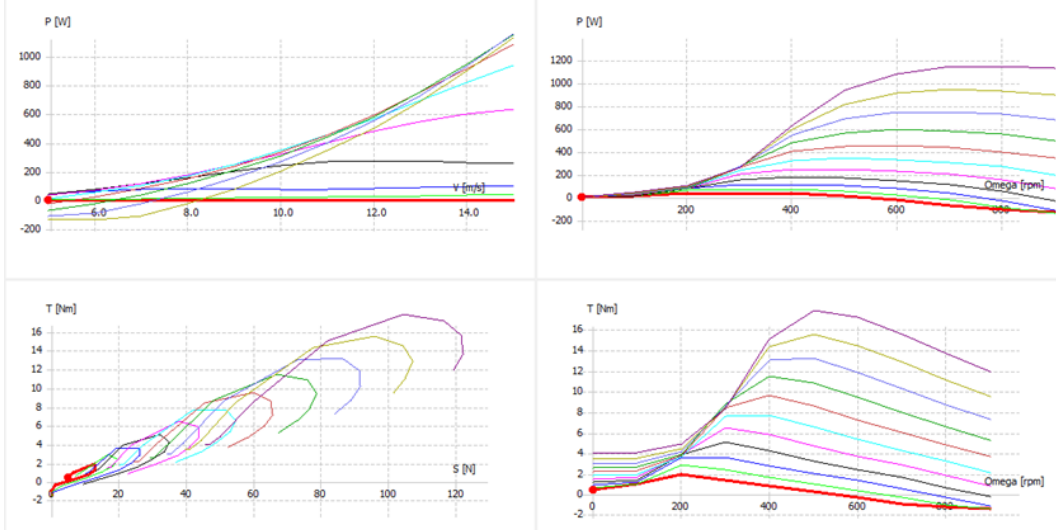

Gambar 6. Hasil Performance turbin angin sumbu horizontal 6 blade pada sudut pitch $0^{\circ}$

Dari Gambar 6 didapatkan data bahwa Power paling besar pada besar ketika kecepatan $20 \mathrm{~m} / \mathrm{s}$ dengan kecepatan rotasi $1001,00 \mathrm{rpm}$ yaitu 2806,3 watt, untuk power yang cenderung stabil, saat kecepatan rotasi $\leq 501,00 \mathrm{rpm}$ akan turun pada kecepatan angin $10 \mathrm{~m} / \mathrm{s}$ sampai dengan $14 \mathrm{~m} / \mathrm{s}$. Rotor torque yang di hasilkan paling besar adalah ketika kecepatan angin $20 \mathrm{~m} / \mathrm{s}$ dan kecepatan rotasi 601,00 rpm yaitu 34,5 Nm dengan Thrust 197,065 N, nilai thrust paling besar ketika kecepatan rotasi 1001,00 rpm yaitu 237,631 $\mathrm{N}$. Dari data yang ditunjukan grafik dapat di ketahui bahwa grafik $\mathrm{T}$ vs rpm mengalami penurunan nilai rotor torque yang signifikan pada kecepata rotasi 801,00 rpm. Hasil grafik pada turbin angin dengan 6 blade dengan sudut pitch $6^{\circ}$ dapat di lihat di Gambar 8. 

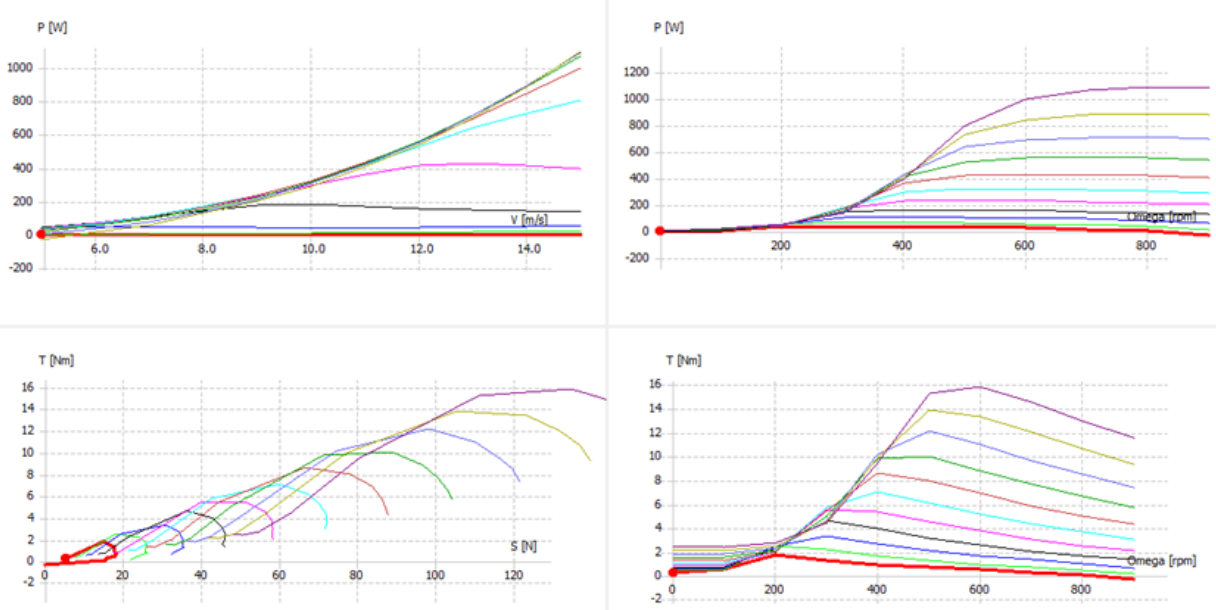

Gambar 7. Hasil Performance turbin angin sumbu horizontal 6 blade pada sudut pitch $6^{\circ}$

Dari Gambar 7 didapatkan data bahwa Power paling besar pada besar ketika kecepatan $20 \mathrm{~m} / \mathrm{s}$ dengan kecepatan rotasi $1101,00 \mathrm{rpm}$ yaitu 2487,45 watt, untuk power cenderung stabil, saat kecepatan rotasi $\leq 501,00 \mathrm{rpm}$ power akan turun pada kecepatan angin $10 \mathrm{~m} / \mathrm{s}$ sampai dengan $15 \mathrm{~m} / \mathrm{s}$, sementara untuk kecepatan rotasi 1301,001 rpm samapai 1401,00 power akan naik secara drastis pada kecepatan paada kecepatan $8 \mathrm{~m} / \mathrm{s}$ sampai dengan $9 \mathrm{~m} / \mathrm{s}$. Rotor torque yang di hasilkan paling besar adalah ketika kecepatan angin $20 \mathrm{~m} / \mathrm{s}$ dan kecepatan rotasi 701,00 rpm yaitu 29,55 Nm dengan Thrust 242,499 N, nilai thrust paling besar ketika kecepatan rotasi 1401,00 rpm yaitu 299,47 N. Dari data yang di tunjukan grafik dapat di ketahui bahwa grafik $\mathrm{T}$ vs rpm mengalami penurunan nilai rotor torque yang signifikan mulai kecepatan rotasi $801,00 \mathrm{rpm}$. Untuk power cenderung stabil saat kecepatan rotasi $\geq 801,00 \mathrm{rpm}$. Hasil grafik pada turbin angin dengan 6 blade dengan sudut pitch $10^{\circ}$
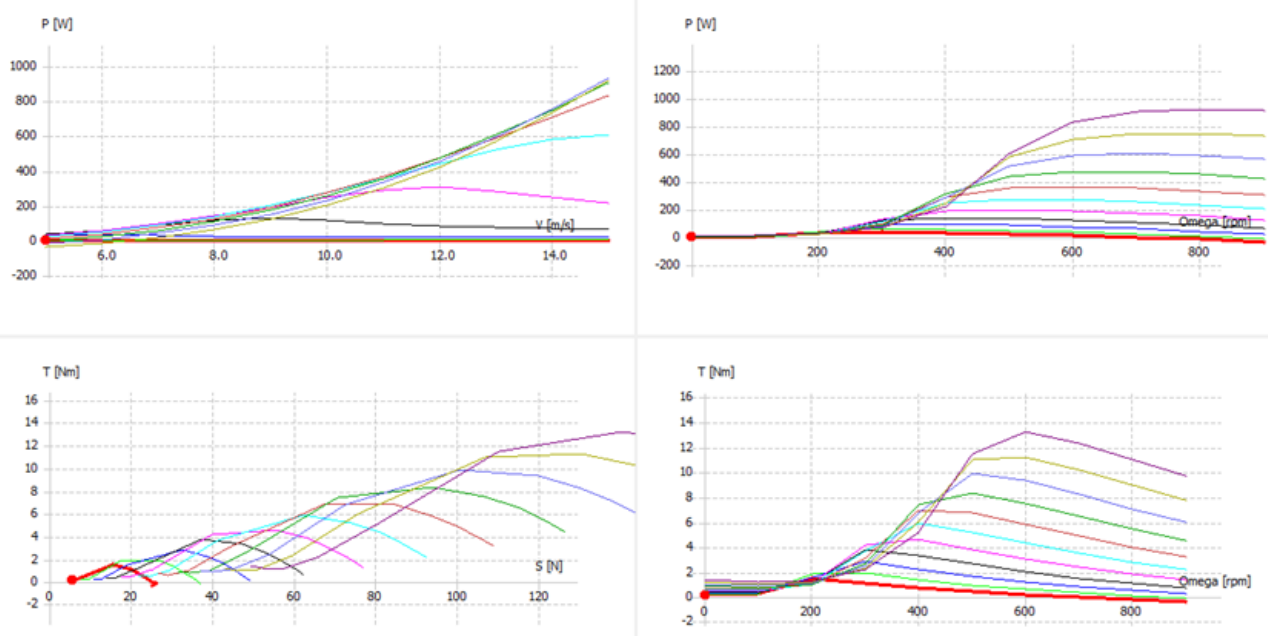

Gambar 8. Hasil Performance turbin angin sumbu horizontal 6 blade pada sudut pitch $10^{\circ}$

Pada Gambar 8 telah didapatkan hasil performance bahwa power paling besar adalah 2101,7 watt saat kecepatan angin $20 \mathrm{~m} / \mathrm{s}$ dan kecepatan rotasi $1001,00 \mathrm{rpm}$, dari grafik $\mathrm{P}$ vs V power cenderung stabil untuk naik dan tidak ada penurun power seiring bertambahnya kecepatan angin. Rotor torque yang di hasilkan besar saat kecepatan angin $20 \mathrm{~m} / \mathrm{s}$ dan kecepatan rotasi 701,00 rpm yaitu 24,13 Nm dengan thrust yang di hasilkan 247,72 N, untuk Thrust paling besar didapatkan nilai 363,11 N saat kecepatan angin 20 $\mathrm{m} / \mathrm{s}$ dan kecepatan rotasi 1401,00 rpm. 
Dari data dia atas dapat di simpulkan bahwa power paling besar ketika sudut pitch $0^{\circ}$ dengan power yaitu 2806,3 watt, dan terdapat peningkatan nilai thrust di mana semakin besar sudut pitch juga maka akan semakin besar nilai thrust yang di hasilkan.

Dalam penelitian ini juga melakukan analisis Performance turbin angin sumbu horizontal 4 blade dan 5 blade dimana tabel hasil perhitungan tidak dicantumkan dalam jurnal ini. Kemudian tabel dibawah ini khusus hasil pengujian performance turbin angin terhadap rata-rata kecepatan angin di Indonesia yaitu 12 $\mathrm{m} / \mathrm{s}$ dan untuk kecepatan rotasi maksimal $300 \mathrm{rpm}$ untuk turbin angin skala kecil, adapun hasil percobaan dapat di lihat di tabel 5 dan 6.

Tabel 5. Hasil performance turbin angin 3 blade dan 4 blade

\begin{tabular}{|c|c|c|c|c|c|c|c|c|c|}
\hline \multirow{2}{*}{\multicolumn{5}{|c|}{$\begin{array}{c}\text { Performance turbin dengan } 3 \text { blade } \\
\text { Sudut pitch } 0^{\circ}\end{array}$}} & \multicolumn{5}{|c|}{ Performance turbin dengan 4 blade } \\
\hline & & & & & \multicolumn{5}{|c|}{ Sudut pitch $0^{\circ}$} \\
\hline \multicolumn{5}{|c|}{$\mathrm{P}$ (Watt) } & No & $\begin{array}{c}\mathrm{V} \\
(\mathrm{m} / \mathrm{s})\end{array}$ & $\mathrm{P}$ (Watt) & $\mathrm{T}(\mathrm{Nm})$ & $\mathrm{S}(\mathrm{N})$ \\
\hline 1 & 3 & 3,358 & 0,107 & 2,155 & 1 & 3 & 3,257 & 0,103 & 2,414 \\
\hline 2 & 4 & 16,871 & 0,535 & 6,017 & 2 & 4 & 17,935 & 0,569 & 6,894 \\
\hline 3 & 5 & 36,300 & 1,152 & 10,137 & 3 & 5 & 40,067 & 1,271 & 12,008 \\
\hline 4 & 6 & 60,741 & 1,927 & 14,253 & 4 & 6 & 69,292 & 2,198 & 17,300 \\
\hline 5 & 7 & 88,092 & 2,795 & 18,106 & 5 & 7 & 103,343 & 3,279 & 22,428 \\
\hline 6 & 8 & 114,383 & 3,629 & 21,232 & 6 & 8 & 139,998 & 4,441 & 27,279 \\
\hline 7 & 9 & 135,146 & 4,288 & 23,641 & 7 & 9 & 172,509 & 5,473 & 31,076 \\
\hline 8 & 10 & 149,943 & 4,757 & 25,644 & 8 & 10 & 196,804 & 6,244 & 33,909 \\
\hline 9 & 11 & 155,058 & 4,919 & 27,226 & 9 & 11 & 209,787 & 6,656 & 36,388 \\
\hline 10 & 12 & 152,676 & 4,844 & 28,900 & 10 & 12 & 211,856 & 6,721 & 38,488 \\
\hline \multicolumn{5}{|c|}{${\text { Sudut pitch } 6^{\circ}}^{\circ}$} & \multicolumn{5}{|c|}{ Sudut pitch $6^{\circ}$} \\
\hline No & $\begin{array}{c}\mathrm{V} \\
(\mathrm{m} / \mathrm{s})\end{array}$ & $\mathrm{P}$ (Watt) & $\mathrm{T}(\mathrm{Nm})$ & $\mathrm{S}(\mathrm{N})$ & No & $\begin{array}{c}\mathrm{V} \\
(\mathrm{m} / \mathrm{s})\end{array}$ & $\mathrm{P}$ (Watt) & $\mathrm{T}(\mathrm{Nm})$ & $\mathrm{S}(\mathrm{N})$ \\
\hline 1 & 3 & 9,079 & 0,288 & 5,852 & 1 & 3 & 8,008 & 0,254 & 6,159 \\
\hline 2 & 4 & 22,539 & 0,715 & 10,008 & 2 & 4 & 21,462 & 0,681 & 11,000 \\
\hline 3 & 5 & 42,950 & 1,363 & 14,448 & 3 & 5 & 42,305 & 1,342 & 16,378 \\
\hline 4 & 6 & 66,146 & 2,098 & 18,311 & 4 & 6 & 70,921 & 2,250 & 21,982 \\
\hline 5 & 7 & 87,357 & 2,771 & 21,043 & 5 & 7 & 101,887 & 3,232 & 26,795 \\
\hline 6 & 8 & 101,372 & 3,216 & 22,856 & 6 & 8 & 127,158 & 4,034 & 30,012 \\
\hline 7 & 9 & 103,279 & 3,277 & 23,996 & 7 & 9 & 139,686 & 4,432 & 32,244 \\
\hline 8 & 10 & 97,064 & 3,079 & 25,172 & 8 & 10 & 136,742 & 4,338 & 33,742 \\
\hline 9 & 11 & 89,589 & 2,842 & 26,992 & 9 & 11 & 126,495 & 4,013 & 35,680 \\
\hline 10 & 12 & 82,568 & 2,619 & 29,55 & 10 & 12 & 117,207 & 3,718 & 38,728 \\
\hline \multicolumn{5}{|c|}{ Sudut pitch $10^{\circ}$} & \multicolumn{5}{|c|}{ Sudut pitch $10^{\circ}$} \\
\hline No & $\begin{array}{l}\mathrm{V} \\
(\mathrm{m} / \mathrm{s})\end{array}$ & $\mathrm{P}$ (Watt) & $\mathrm{T}(\mathrm{Nm})$ & $\mathrm{S}(\mathrm{N})$ & No & $\begin{array}{l}\mathrm{V} \\
(\mathrm{m} / \mathrm{s})\end{array}$ & $\mathrm{P}$ (Watt) & $\mathrm{T}(\mathrm{Nm})$ & $\mathrm{S}(\mathrm{N})$ \\
\hline 1 & 3 & 6,965 & 0,221 & 7,348 & 1 & 3 & 5,685 & 0,180 & 8,026 \\
\hline 2 & 4 & 19,154 & 0,608 & 11,652 & 2 & 4 & 17,352 & 0,550 & 13,051 \\
\hline 3 & 5 & 37,564 & 1,192 & 16,054 & 3 & 5 & 35,630 & 1,130 & 18,476 \\
\hline 4 & 6 & 60,595 & 1,922 & 19,687 & 4 & 6 & 60,218 & 1,910 & 23,884 \\
\hline 5 & 7 & 75,151 & 2,384 & 21,617 & 5 & 7 & 86,632 & 2,748 & 27,902 \\
\hline 6 & 8 & 74,989 & 2,379 & 22,379 & 6 & 8 & 101,597 & 3,223 & 30,256 \\
\hline
\end{tabular}




\begin{tabular}{cccccccccc}
7 & 9 & 65,606 & 2,081 & 23,307 & 7 & 9 & 95,733 & 3,037 & 31,341 \\
8 & 10 & 55,429 & 1,759 & 25,180 & 8 & 10 & 82,367 & 2,613 & 33,153 \\
9 & 11 & 48,040 & 1,524 & 27,631 & 9 & 11 & 69,377 & 2,201 & 36,178 \\
10 & 12 & 43,608 & 1,383 & $\mathbf{3 0 , 5 8 9}$ & 10 & 12 & 62,211 & 1,974 & 39,857 \\
\hline
\end{tabular}

Tabel 6. Hasil performance turbin angin 5 balde dan 6 blade

\begin{tabular}{|c|c|c|c|c|c|c|c|c|c|}
\hline \multicolumn{5}{|c|}{ Performance turbin dengan 5 blade } & \multicolumn{5}{|c|}{ Performance turbin dengan 6 blade } \\
\hline \multirow[b]{2}{*}{ No } & \multicolumn{4}{|c|}{ Sudut pitch $0^{\circ}$} & \multicolumn{5}{|c|}{ Sudut pitch $0^{\circ}$} \\
\hline & $\mathrm{V}(\mathrm{m} / \mathrm{s})$ & $\mathrm{P}$ (Watt) & $\mathrm{T}(\mathrm{Nm})$ & $\mathrm{S}(\mathrm{N})$ & No & $\mathrm{V}(\mathrm{m} / \mathrm{s})$ & $\mathrm{P}$ (Watt) & $\mathrm{T}(\mathrm{Nm})$ & $\mathrm{S}(\mathrm{N})$ \\
\hline 1 & 3 & 2,767 & 0,088 & 2,508 & 1 & 3 & 2,382 & 0,076 & 2,621 \\
\hline 2 & 4 & 18,330 & 0,582 & 7,473 & 2 & 4 & 18,355 & 0,582 & 7,843 \\
\hline 3 & 5 & 41,488 & 1,316 & 13,250 & 3 & 5 & 41,943 & 1,331 & 14,105 \\
\hline 4 & 6 & 73,919 & 2,345 & 19,702 & 4 & 6 & 75,738 & 2,403 & 21,377 \\
\hline 5 & 7 & 113,411 & 3,598 & 26,163 & 5 & 7 & 117,266 & 3,720 & 28,696 \\
\hline 6 & 8 & 157,806 & 5,006 & 32,402 & 6 & 8 & 167,685 & 5,320 & 36,224 \\
\hline 7 & 9 & 201,678 & 6,398 & 37,680 & 7 & 9 & 221,915 & 7,040 & 43,484 \\
\hline 8 & 10 & 237,439 & 7,533 & 41,852 & 8 & 10 & 271,660 & 8,618 & 49,343 \\
\hline 9 & 11 & 263,815 & 8,370 & 45,445 & 9 & 11 & 310,561 & 9,853 & 53,890 \\
\hline 10 & 12 & 273,977 & 8,692 & 48,175 & 10 & 12 & 332,383 & 10,545 & 57,852 \\
\hline
\end{tabular}

\begin{tabular}{|c|c|c|c|c|c|c|c|c|c|}
\hline \multicolumn{5}{|c|}{ Sudut pitch $6^{\circ}$} & \multicolumn{5}{|c|}{${\text { Sudut pitch } 6^{\circ}}^{\circ}$} \\
\hline No & $\mathrm{V}(\mathrm{m} / \mathrm{s})$ & $\mathrm{P}$ (Watt) & $\mathrm{T}(\mathrm{Nm})$ & $\mathrm{S}(\mathrm{N})$ & No & $\mathrm{V}(\mathrm{m} / \mathrm{s})$ & $\mathrm{P}$ (Watt) & $\mathrm{T}(\mathrm{Nm})$ & $\mathrm{S}(\mathrm{N})$ \\
\hline 1 & 3 & 7,422 & 0,235 & 6,507 & 1 & 3 & 6,651 & 0,211 & 6,655 \\
\hline 2 & 4 & 19,853 & 0,630 & 11,561 & 2 & 4 & 18,598 & 0,590 & 12,008 \\
\hline 3 & 5 & 40,206 & 1,276 & 17,616 & 3 & 5 & 38,460 & 1,220 & 18,569 \\
\hline 4 & 6 & 69,050 & 2,191 & 24,250 & 4 & 6 & 67,135 & 2,130 & 25,923 \\
\hline 5 & 7 & 104,583 & 3,318 & 30,876 & 5 & 7 & 103,772 & 3,292 & 33,540 \\
\hline 6 & 8 & 143,801 & 4,562 & 36,434 & 6 & 8 & 145,105 & 4,604 & 40,656 \\
\hline 7 & 9 & 172,514 & 5,473 & 40,081 & 7 & 9 & 190,056 & 6,030 & 46,839 \\
\hline 8 & 10 & 180,561 & 5,728 & 42,480 & 8 & 10 & 216,032 & 6,854 & 51,017 \\
\hline 9 & 11 & 170,536 & 5,410 & 44,503 & 9 & 11 & 215,629 & 6,841 & 53,676 \\
\hline 10 & 12 & 157,169 & 4,986 & 47,641 & 10 & 12 & 199,297 & 6,323 & 56,643 \\
\hline
\end{tabular}

\begin{tabular}{|c|c|c|c|c|c|c|c|c|c|}
\hline \multicolumn{5}{|c|}{ Sudut pitch $1^{\circ}$} & \multicolumn{5}{|c|}{ Sudut pitch $1^{\circ}$} \\
\hline No & $\mathrm{V}(\mathrm{m} / \mathrm{s})$ & P (Watt) & $\mathrm{T}(\mathrm{Nm})$ & $\mathrm{S}(\mathrm{N})$ & No & $\mathrm{V}(\mathrm{m} / \mathrm{s})$ & $\mathrm{P}$ (Watt) & $\mathrm{T}(\mathrm{Nm})$ & $\mathrm{S}(\mathrm{N})$ \\
\hline 1 & 3 & 4,580 & 0,145 & 8,533 & 1 & 3 & 3,529 & 0,112 & 8,873 \\
\hline 2 & 4 & 15,487 & 0,491 & 14,048 & 2 & 4 & 13,806 & 0,438 & 14,805 \\
\hline 3 & 5 & 33,781 & 1,072 & 20,305 & 3 & 5 & 31,523 & 1,000 & 21,689 \\
\hline 4 & 6 & 58,441 & 1,854 & 26,714 & 4 & 6 & 56,767 & 1,801 & 28,981 \\
\hline 5 & 7 & 87,888 & 2,788 & 32,687 & 5 & 7 & 87,580 & 2,779 & 36,532 \\
\hline 6 & 8 & 117,551 & 3,729 & 37,055 & 6 & 8 & 122,102 & 3,874 & 43,013 \\
\hline 7 & 9 & 130,131 & 4,128 & 39,730 & 7 & 9 & 148,262 & 4,704 & 47,339 \\
\hline 8 & 10 & 114,069 & 3,619 & 41,250 & 8 & 10 & 150,883 & 4,787 & 49,949 \\
\hline 9 & 11 & 96,300 & 3,055 & 44,471 & 9 & 11 & 129,641 & 4,113 & 52,579 \\
\hline
\end{tabular}




\section{Kesimpulan}

Nilai power paling besar pada turbin dengan jumlah 3 blade, dengan sudut $6^{\circ}$ yaitu 2837 watt saat kecepatan angin $20 \mathrm{~m} / \mathrm{s}$ dan 1401,00 rpm, turbin ini sangat cocok untuk pembagkit listrik tenaga angin. Nilai rotor torque terbesar pada turbin dengan jumlah 6 blade dengan sudut pitch $0^{\circ}$ yaitu $34,5 \mathrm{Nm}$ pada kecepatan angin $20 \mathrm{~m} / \mathrm{s}$ dan kecepatan rotasi $601,00 \mathrm{rpm}$ turbin ini cocok di gunakan untuk turbin angin untuk pompa di karenakan mempunyai tenaga torque atau putar yang besar. Nilai thrust terbesar pada percobaan ini dihasilkan oleh turbin angin dengan jumlah 6 blade dengan sudut $10^{\circ}$ yaitu $363,11 \mathrm{~N}$, ketika kecepatan angin $20 \mathrm{~m} / \mathrm{s}$ dan kecepatan rotasi 1401,00 rpm. Untuk turbin dengan kecepatan rotasi yang besar di atas $1301.00 \mathrm{rpm}$ tidak efektif di gunakan pada angin dengan kecepatan rendah di bawah $11 \mathrm{~m} / \mathrm{s}$ di karenakan power untuk dari putran turbin tidak terpenuhi. Untuk turbin dengan kecepetan rendah juga tidak efektif bila di gunakan angin dengan kecepatan tinggi di atas $12 \mathrm{~m} / \mathrm{s}$ karena akan megalami penurunan power. Turbin Angin dengan jumlah 3 Blade, sudut pitch paling efisien adalah sudut pitch $6^{\circ}$ dengan nilai power dan rotor torque terbesar dari ketiga sudut pitch yang di uji. Turbin Angin dengan 4 buah Blade sudut pitch paling efisien adalah sudut pitch $6^{\circ}$ dengan nilai power dan rotor torque besar dengan performance lebih baik dari ketiga sudut pitch yang di uji. Turbin Angin dengan 5 buah Blade sudut pitch paling efisien adalah sudut pitch $0^{\circ}$ dengan nilai power dan rotor torque terbesar dari ketiga sudut pitch yang di uji. Turbin angin dengan 6 buah Blade sudut pitch paling efisien adalah sudut pitch $0^{\circ}$ dengan nilai power dan rotor torque terbesar dari ketiga sudut pitch yang di uji. Sudut pitch paling baik dari beberapa variasi jumlah blade adalah sudut $0^{\circ}$ dimana pada jumlah 5 blade dan 6 blade memiliki power dan rotor torque yang besar, pada sudut ini semakin banyak blade semakin besar nilai power dan di ikuti dengan nilai rotor torque. Turbin angin yang diuji pada kecepatan angin rata-rata di Indonesia yaitu dengan kecepatan $12 \mathrm{~m} / \mathrm{s}$ dan kecepatan rotasi $300 \mathrm{rpm}$ di dapatkan turbin angin paling efesien adalah dengan jumah blade 6 dengan power 332,383 watt, rotor torque 610,545 Nm dan thrust 57,582, untuk sudut pitch paling efisien adalah sudut pitch $0^{\circ}$ untuk setiap variasi jumlah blade yang di uji. Penelitian mendatang, disarankan untuk melakukan rancang bangun menggunakan spesifikasi turbin angin paling efesien dari hasil penelitian ini.

\section{Daftar Pustaka}

[1] Martin O. L. Hansen, 2008. Aerodynamics of Wind Turbin, Second Edition, Earthscan, London.

[2] Veeksha Rao Ponakala, Design and Simulation of Small Wind Turbine Blades in Q-Blade, IJEDR Volume 5 Issue 4 ISSN: 2321-9939. 2017.

[3] Contaned Energy Indonesia, Buku Panduan Energi Terbarukan, Kementerian Dalam Negeri, ISBN 1-885203-29-2.

[4] Pengenalan Teknologi Pemanfaatan Energi Angin, Lentera Angin Nusantara, 2014.

[5] Deibanehbok Nongdhar, Bikramjit Goswami, Pallav Gogoi, Sidharth Borkataky, Design of Horizontal Axis Micro Wind Turbine for Low Wind Speed Areas, ADBU Journal of Electrical and Electronics Engineering (AJEEE) Volume 2, Issue 2, September 2018.

[6] Dalibor Rozehnal, and Jakub Hnidka, Performance analysis of a horizontal axis wind turbine, MATEC Web of Conferences 313, 00052 (2020).

[7] Khin Kyawt Kyawt Lin, Zin Ei Ei Win, Saw Ba Tin, Design and Stress Analysis of Horizontal Axis Wind Turbine Blade $(1 \mathrm{~kW})$, International Journal of Science, Engineering and Technology Research (IJSETR) Volume 7, Issue 10, October 2018, ISSN: 2278 -7798.

[8] Shafiqur Rehman, Md. Mahbub Alam, Luai M. Alhems and M. Mujahid Rafique, Horizontal Axis Wind Turbine Blade Design Methodologies for Efficiency Enhancement, Energies 2018, 11, 506; doi:10.3390/en11030506.

[9] Ghofur, M.A. 2019. "Rancang Bangun Konfigurasi Three Straight Blade Vertical Axis Wind Turbin GR-1”. Prosiding Senastindo AAU 2019 ISSN 2685-8991.

[10] Firman Aryanto, I Made Mara, Made Nuarsa. 2013. Pengaruh Kecepatan Angin Dan Variasi Jumlah Sudu Terhadap Unjuk Kerja Turbin Angin Poros Horizontal. Dinamika Teknik Mesin, Volume 3 No. 3 ISSN:2088-088X Jurusan Teknik Mesin Fakultas Teknik Universitas Mataram.

[11] Bono. 2012. Kaji Eksperimen Turbin Angin Poros Horizontal Tipe Kerucut Terpancung Dengan Variasai Sudut Sudu Untuk Pembangkit Listrik Tenaga Angin. Prosiding SNST Ke-3 ISBN 978- 
602-99334-1-3. Jurusan Teknik Mesin Fakultas Teknik Mesin Universitas Wahid Hasyim Semarang.

[12] Arga Gideon Sarwando, Untung Budiarto, Ahmad Fauzan Zakki. 2016. Analisa Efektifitas Wind Turbine Sumbu Horizontal Dengan Variasi Jumlah dan Jenis Airfoil Sebagai Sumber Energi Listrik Tambahan Pada Fisheries Inspection. Jurnal Teknik Perkapalan Volume 4 no. 4. Departemen Teknik Perkapalan Fakultas Teknik Universitas Diponegoro. 